\title{
«La désignation territoriale des quatre spâhbed de l'empire sassanide d'après les sources primaires sigillographiques ». St. Ir. 30, 1 (2001), pp. 137-141.
}

\section{Rémy Boucharlat}

\section{(2) OpenEdition}

1 Journals

\section{Édition électronique}

URL : http://journals.openedition.org/abstractairanica/34352

DOI : 10.4000/abstractairanica.34352

ISSN : 1961-960X

Éditeur :

CNRS (UMR 7528 Mondes iraniens et indiens), Éditions de l'IFRI

\section{Édition imprimée}

Date de publication : 15 mai 2003

ISSN : 0240-8910

Référence électronique

Rémy Boucharlat, « «La désignation territoriale des quatre spâhbed de l'empire sassanide d'après les sources primaires sigillographiques ». St. Ir. 30, 1 (2001), pp. 137-141. », Abstracta Iranica [En ligne], Volume 24 | 2003, document 87, mis en ligne le 05 janvier 2010, consulté le 25 septembre 2020. URL : http://journals.openedition.org/abstractairanica/34352 ; DOI : https://doi.org/10.4000/ abstractairanica.34352

Ce document a été généré automatiquement le 25 septembre 2020.

Tous droits réservés 
« La désignation territoriale des quatre spâhbed de l'empire sassanide d'après les sources primaires sigillographiques ». St. Ir. 30, 1 (2001), pp. 137-141.

\section{Rémy Boucharlat}

1 À propos des empreintes de sceaux étudiées dans c.r. n ${ }^{\circ 9}$, l'A. montre la valeur des sources primaires, tel que les sceaux, par rapport aux sources littéraires, plus tardives. Ces dernières sont souvent approximatives; dans le cas présent, elles modifient le titre original de ces hauts dignitaires.

\section{INDEX}

Thèmes : 3.2.3. Séleucides, Parthes et Sassanides

\section{AUTEURS}

RÉMY BOUCHARLAT

CNRS - Lyon 